\title{
Overall Skin Health Potential of the Biofield Energy Healing Based Herbomineral Formulation Using Various Skin Parameters
}

\author{
Janice Patricia Kinney ${ }^{1}$, Mahendra Kumar Trivedi ${ }^{1}$, Alice Branton ${ }^{1}$, Dahryn Trivedi ${ }^{1}$, \\ Gopal Nayak ${ }^{1}$, Sambhu Charan Mondal' ${ }^{2}$, Snehasis Jana ${ }^{2, *}$ \\ ${ }^{1}$ Trivedi Global, Inc., Henderson, USA \\ ${ }^{2}$ Trivedi Science Research Laboratory Pvt. Ltd., Bhopal, India
}

Email address:

publication@trivedisrl.com (S. Jana)

${ }^{*}$ Corresponding author

\section{To cite this article:}

Janice Patricia Kinney, Mahendra Kumar Trivedi, Alice Branton, Dahryn Trivedi, Gopal Nayak, Sambhu Charan Mondal, Snehasis Jana. Overall Skin Health Potential of the Biofield Energy Healing Based Herbomineral Formulation Using Various Skin Parameters. American Journal of Life Sciences. Vol. 5, No. 2, 2017, pp. 65-74. doi: 10.11648/j.ajls.20170502.15

Received: March 30, 2017; Accepted: April 19, 2017; Published: May 8, 2017

\begin{abstract}
The aim of the present study was to evaluate the effect of the Consciousness Energy Healing (The Trivedi Effect ${ }^{\circledR}$ ) Treatment based test formulation and medium (DMEM) against various skin health parameters using three cell lines i.e., HFF$1, \mathrm{HaCaT}$, and B16-F10. The various study parameters viz. collagen, elastin, hyaluronic acid, melanin, cell viability against UV-B induced stress, and wound healing were evaluated. The test formulation and DMEM were divided into two parts. One part of the test formulation and one part of the DMEM received the Consciousness Energy Healing Treatment by Janice Patricia Kinney and were defined as the Biofield Energy Treated samples, while the other parts were denoted as the untreated test samples. Cell viability using MTT assay showed more than $70 \%$ cells were viable in all the tested concentrations in three cells, indicating that the test formulation was safe and nontoxic. The collagen synthesis was significantly $(p \leq 0.001)$ increased by $22.42 \%$ and $17.48 \%$ in the UT-DMEM + BT-Test formulation group at 0.63 and $2.5 \mu \mathrm{g} / \mathrm{mL}$, respectively in relation to the UT-DMEM + UT-Test formulation group. The Elastin level was significantly $(p \leq 0.001)$ increased by $28.41 \%$ in the BTDMEM + BT-Test formulation group at $5 \mu \mathrm{g} / \mathrm{mL}$ compared to the untreated group. Hyaluronic acid at $0.63 \mu \mathrm{g} / \mathrm{mL}$ was increased significantly by $15.90 \%$ in the BT-DMEM + BT-Test formulation group compared to the untreated group. The level of melanin was reduced significantly by $9.25 \%$ and $7.26 \%$ in the BT-DMEM + BT-Test formulation group at 0.013 and 0.063 $\mu \mathrm{g} / \mathrm{mL}$, respectively in relation to the untreated group. Protection of skin cells after UV-B exposure data displayed that the cell viability was increased significantly by $17.88 \%, 20.10 \%$, and $25.77 \%$ in the BT-DMEM + BT-Test formulation group at 0.625 , 1.25 , and $2.5 \mu \mathrm{g} / \mathrm{mL}$, respectively compared to the UT-DMEM + UT-Test formulation group. Wound healing data exhibited significant wound closure and cell migration activities in the HFF-1 and HaCaT cells compared to the UT-DMEM + UT-Test formulation. Overall, the data suggests that the Biofield Energy Treated DMEM and test formulation demonstrated better responses compared to the untreated medium and test formulation with respect to the tested skin health parameters. Therefore, the Biofield Energy Healing and the Treated test formulation could be developed as an effective cosmetic product to protect and treat the various skin problems including infection, photosensitivity, erythema, contact dermatitis, seborrheic dermatitis, athlete's foot, psoriasis, erythema, cutis rhomboidalis nuchae, skin aging, wrinkles and/or change in skin color, etc.
\end{abstract}

Keywords: Consciousness Energy Healing, The Trivedi Effect ${ }^{\circledR}$, Skin Protection, HFF-1; B16-F10, HaCaT, Scratch Assay, Extracellular Matrix 


\section{Introduction}

The demand of herbal-based cosmetics continues to increase across the world today due to the lower prevalence of human health hazards and side effects versus other common treatments [1]. Many invasive and non-invasive skin treatment measures such as gene therapy, chemical peels, and several devices such as laser energy, injectables, etc. are used for skin health and rejuvenation [2, 3], however many photo-aging products, antioxidant agents (i.e. vitamin $\mathrm{B}_{3}, \mathrm{C}$, and E) are also available in the market for skin health. The new cosmetic market is driven with the utilization of herbal drugs, cosmetics, nutraceuticals, and natural dyes. However, herbomineral products are the best way to utilize the modern as well as holistic aspect. The present research work evaluates a novel cosmetic product, an herbomineral formulation was prepared in order to improve the overall skin health using different skin health parameters in three cells lines such as human foreskin fibroblast (HFF-1), human keratinocytes (HaCaT) and mouse melanoma (B16-F10). The novel proprietary herbomineral based formulation was prepared consisting of essential minerals (zinc chloride, sodium selenate, and sodium molybdate), vitamin (Lascorbic acid), tetrahydrocurcumin (THC), and herbal extract (Centella asiatica; C. asiatica). Each ingredient already has been proven for its potential activity on skin health in various medicine as well as cosmeceuticals. From the literature point of view, zinc acts as an essential cofactor of various metalloenzymes and it protects the skin from UV irradiation. Further it has been widely used in the early $19^{\text {th }}$ century as a destructive agent for the management of cancer $[4,5]$. Sodium selenate can enhance the repair system of DNA segments and also reduces the risk of new cancer development in a low concentration [6, 7]. Researchers reported that it prevents skin cancers in the form of the supplement with L-selenomethionine [8, 9]. Molybdenum is an essential element for humans, animals, and plants and acts as a key constituent of various important enzymes [10, 11]. Vitamin C plays a vital role in the repair of damaged skin and modulates the collagen production [12]. Tetrahydrocurcumin (THC) exhibits the strongest antioxidant property and has been routinely used as a skin care formulation for the treatment of various skin related problems [13, 14]. The herbal extract of $C$. asiatica can enhance the process of wound healing and provides significant benefits in skin care products. Hashim et al. reported that $C$. asiatica leaves extract can enhance the synthesis of collagen and has potential antioxidant, anti-cellulite, and UV protectant activities. It is also used in proprietary medicinal products for the treatment of cutaneous ulcer, hypertrophic scars, keloids, and wound healing disorders [15-17].

Based on Ampere's scientific theory it was elaborated that all the electrical processes happening in the human body or in any other living organisms have a strong relationship with the magnetic fields $[18,19]$. Thus, a human body emits the electromagnetic waves in the form of bio-photons also called ultraweak photon emissions (UPE). It surrounds the body and commonly known as the "Biofield". The transfer of information from cell-to-cell or DNA or storage by biophotons has been demonstrated in plants, bacteria, animal neutrophil granulocytes and kidney cells [20]. Thus, a Biofield Healing Practitioner has the ability to harness the energy from the environment and can transmit it into any object (living organism or non-living materials) around the globe. The object(s) always receive the energy and respond in a useful way, that is called "Biofield Energy Treatment". This process is known as "Biofield Energy Healing". Biofield Energy Healing has been approved as an alternative method that has an impact on various properties of living organisms in a cost-effective manner [21]. Recent studies reported that the uses of energy medicine provided the highest benefit to cancer patients as compared to the use of other Complementary and Alternative Medicine (CAM) [22]. The Trivedi Effect ${ }^{\circledR}$ unique Biofield Energy Treatment has been known to alter the response in a wide-spectrum field in living and non-living systems viz. materials science [23-25], agriculture [26, 27], microbiology [28-30] biotechnology [31, 32]. Based on the excellent outcome of the Biofield Energy Treatment, authors designed this study to investigate the impact of the Biofield Energy Healing based DMEM and test formulation on various skin health parameters using three cell lines such as human foreskin fibroblast (HFF-1), human keratinocytes (HaCaT), and mouse melanoma (B16-F10).

\section{Materials and Methods}

\subsection{Chemicals and Reagents}

Zinc chloride was purchased from TCI, Japan, sodium selenate from Alfa-Aesar, USA, while sodium molybdate from Sigma-Aldrich, USA. L-ascorbic acid was purchased from Alfa-Aesar, while kojic acid was purchased from Sigma, USA. Fetal bovine serum (FBS) and Dulbecco's Modified Eagle's Medium (DMEM) were purchased from Gibco, USA. Epidermal growth factor (EGF) was procured from Gibco, ThermoFisher, USA. ELISA kits were procured from CUSABIO and CusAb Co. Pvt. Ltd., USA. Tetrahydrocurcumin and Centella asiatica extract were procured from Novel Nutrients Pvt. Ltd., India and Sanat Products Ltd., India, respectively. Antibiotics solution (penicillin-streptomycin) was procured from Himedia, India, while 3-(4, 5-diamethyl-2-thiazolyl)-2, 5-diphenyl-2Htetrazolium) (MTT), Direct Red 80 and ethylene diamine tetra acetic acid (EDTA) were purchased from Sigma, USA. All the other chemicals used in this experiment were analytical grade procured from India.

\subsection{Cell Culture}

HFF-1 (human fibroblast) cells were procured from American Type Culture Collection (ATCC), USA, originated from normal human skin fibroblast cells. B16-F10 (mouse melanoma) cells were procured from National Centre for Cell Science (NCCS), Pune. HFF-1, and B16-F10 cell lines were maintained in the growth medium DMEM supplemented 
with $15 \%$ FBS, with added antibiotics penicillin $(100 \mathrm{U} / \mathrm{mL})$ and streptomycin $(100 \mu \mathrm{g} / \mathrm{mL})$. The growth condition of cell lines were $37^{\circ} \mathrm{C}, 5 \% \mathrm{CO}_{2}$, and $95 \%$ humidity. L-ascorbic acid (for ECM, UV-B protection, and wound healing assay) in concentrations ranges from $10 \mu \mathrm{M}$ to $1000 \mu \mathrm{M}$, while kojic acid (for melanin synthesis) concentrations ranges from 1 $\mathrm{mM}$ to $10 \mathrm{mM}$, FBS $(0.5 \%)$ was used in cell proliferation (BrdU) assay, while EGF $10 \mu \mathrm{M}$ was used in MTT assay.

\subsection{Experimental Design}

The experimental groups consisted of cells in normal control, vehicle control group $(0.05 \%$ DMSO), positive control group (L-ascorbic acid/kojic acid/EGF/FBS) and experimental tested groups. Experimental groups included the combination of Biofield Energy Treated and untreated Test formulation/DMEM. It consisted of four major treatment groups on specified cells with UT-DMEM + UT-Test formulation, UT-DMEM + BT-Test formulation, BT-DMEM + UT-Test formulation, and BTDMEM + BT-Test formulation.

\subsection{Consciousness Energy Healing Treatment Strategies}

The test formulation and DMEM were divided into two parts. One of each part was considered as the control samples, while other parts were defined as the treated samples. Both the samples were kept under standard laboratory conditions at the research laboratory of Dabur Research Foundation near New Delhi, India. The treated samples were subjected to Consciousness Energy Healing (The Trivedi Effect ${ }^{\circledR}$ ) Treatment by renowned Biofield Energy Healer (also known as The Trivedi Effect ${ }^{\circledR}$ ), Janice Patricia Kinney remotely for 5 minutes from U.S.A. This Biofield Energy Treatment was exposed for 5 minutes through the Healer's unique Energy Transmission process remotely to the test samples under laboratory conditions. The Biofield Energy Healer, Janice Patricia Kinney in this study never visited the laboratory in person, nor had any contact with the test samples. Similarly, the control samples were subjected to "sham" healer under the same laboratory conditions for 5 minutes. The sham healer did not have any knowledge about the Biofield Energy Treatment. After that, the Biofield Energy Treated and untreated samples were kept in similar sealed conditions and used for this experiment.

\subsection{Determination of Non-cytotoxic Concentration}

MTT assay was performed for the assessment of cell viability in three different cell lines like HFF-1 (human fibroblast), $\mathrm{HaCaT}$ (human keratinocytes), and B16-F10 (mouse melanoma). The cells were counted and plated in 96 well plates at the density corresponding to $5 \times 10^{3}$ to $10 \mathrm{X}$ $10^{3}$ cells/well/180 $\mu \mathrm{L}$ of cell growth medium. The above cells were incubated overnight under growth conditions and allowed the cell recovery and exponential growth, which were subjected to serum stripping or starvation. The cells were treated with test formulation and DMEM/positive controls. The untreated cells were served as the baseline control. The cells in the above plate(s) were incubated for a time point ranging from 24 to 72 hours in $\mathrm{CO}_{2}$ incubator at $37^{\circ} \mathrm{C}, 5 \% \mathrm{CO}_{2}$ and $95 \%$ humidity. Following incubation, the plates were taken out and $20 \mu \mathrm{L}$ of $5 \mathrm{mg} / \mathrm{mL}$ of MTT solution was added to all the wells followed by additional incubation for 3 hours at $37^{\circ} \mathrm{C}$. The supernatant was aspirated and 150 $\mu \mathrm{L}$ of DMSO was added to each well to dissolve formazan crystals. The absorbance of each well was read at $540 \mathrm{~nm}$ using Synergy HT micro plate reader, BioTek, USA. The concentrations exhibiting \% cytotoxicity of $<30 \%$ was considered as non-cytotoxic [33,34]. The percentage of cell viability was calculated using the following Equation 1:

$$
\left.\% \text { Cell viability }=\left(X^{*} 100\right) / R\right)
$$

Where, $\mathrm{X}$ represents the absorbance of the cells corresponding to positive control and test groups and $\mathrm{R}$ represent the absorbance of the cells corresponding to the baseline (control cells) group.

\subsection{Effect of the Test Item on Fibroblast Cell Proliferation by 5-bromo-2'-deoxyuridine (BrdU) Method}

HFF-1 cells were counted using hemocytometer and plated in 96 well plate at the density corresponding to $1 \times 10^{3}$ to 5 $\mathrm{X} 10^{3}$ cells/well in DMEM supplemented with $15 \%$ FBS. The cells/plates were incubated overnight under growth conditions so as to allow cell recovery and exponential growth. Following overnight incubation, the above cells were subjected to serum starvation. Following serum starvation, the cells were treated with non-cytotoxic concentrations of the test substance and positive control. Following 24 to 72 hours of incubation with the test substance and positive control, the plates were taken out and 5-bromo-2'deoxyuridine (BrdU) estimation using cell proliferation ELISA, BrdU estimation kit (ROCHE - 11647229001) as per manufacturer's instructions.

\subsection{Estimation of Extracellular Matrix (ECM)}

Synthesis of extracellular matrices component viz. collagen, elastin, and hyaluronic acid in HFF-1 cells was estimated for determining the potential of the Biofield Energy Treated Test formulation and DMEM to improve the skin strength, elasticity, and the level of hydration. HFF-1 cells were counted using hemocytometer and plated in 48 well plate at the density corresponding to $10 \times 10^{3}$ cells/well in DMEM supplemented with $15 \%$ FBS. The cells were incubated overnight under specified growth conditions followed by cells to serum stripping. Further, the cells were treated with different groups viz. vehicle control (DMSO$0.05 \%$ ), positive control (ascorbic acid, at $10 \mu \mathrm{M}$ concentration), and the test samples at different concentrations. Further, after 72 hours of incubation with the test samples and positive control, the supernatants from all the cell plates were taken out and collected in pre-labeled centrifuge tubes for the estimation of the levels of elastin and hyaluronic acid. However, the corresponding cell layers were processed for the estimation of collagen levels using Direct Sirius red dye binding assay [35]. Elastin and hyaluronic acid 
were estimated using ELISA kits from Cusabio Biotech Co. Ltd., Human Elastin ELN Elisa kit 96T and Human Hyaluronic Acid, Elisa kit 96T, respectively [36].

\subsection{Estimation of Melanin Synthesis}

B16-F10 cells were used for the estimation of melanin synthesis. The cells were counted using hemocytometer and plated in $90 \mathrm{~mm}$ culture dish at the density corresponding to $2 \times 10^{6}$ per $6 \mathrm{~mL}$ in culture plates. Further, the cells were incubated overnight under specified growth conditions and allowed for cell recovery and exponential growth. After incubation, the cells were treated with $\alpha$-melanocytestimulating hormone $(\alpha-\mathrm{MSH})$ for a time point ranging from 4 to 24 hours for the stimulation of intracellular melanin synthesis. Further, the cells were incubated with $\alpha-\mathrm{MSH}$. After incubation, intracellular melanin was extracted in $\mathrm{NaOH}$ and the absorbance was recorded at $405 \mathrm{~nm}$. The level of melanin was extrapolated using a standard curve obtained from purified melanin [37].

\subsection{Anti-wrinkle Effects of the Test Formulation on HFF-1 Cells Against $U V-B$ Induced Stress}

UV-B induced stress was evaluated in HFF-1 cells and the cell viability was estimated in the presence of the test samples. The cells were counted using hemocytometer and plated in 96 well plate at the density corresponding to $5 \times 10^{3}$ to $10 \times 10^{3}$ cells/well in DMEM supplemented with $15 \%$ FBS cells/plate, which were incubated overnight under growth conditions to allow cell recovery and exponential growth. The cells were treated with non-cytotoxic concentrations of test samples for 2 to 24 hours. After treatment with the test samples, the cells were subjected to lethal dose of UV-B irradiation $\left(200 \mathrm{~mJ} / \mathrm{cm}^{2}\right)$ that can lead to approximately $50 \%$ cytotoxicity $(302 \mathrm{~nm}$, CL$1000 \mathrm{M}$, UVP, USA) [38]. The percent cell viability was assessed using the following Equation 2:

$$
\% \text { Cell viability }=\left(\mathrm{X}^{*} 100\right) / \mathrm{R}
$$

Where, $\mathrm{X}$ represents the absorbance of cells corresponding to positive control and test groups, and $\mathrm{R}$ represents the absorbance of cells corresponding to the baseline (control cells) group.

\subsection{Wound Healing Activity by Scratch Assay}

hemocytometer and plated in 12 well plates at the densities $0.08 \times 10^{6} /$ well $/ \mathrm{mL}$ of cell growth medium. The cells $/$ plate were incubated overnight under growth conditions and allowed cell recovery and exponential growth. After overnight incubation, the cells were subjected to the serum starvation in DMEM for 24 hours. Mechanical scratches that represent wounds were created in the near confluent monolayer of cells by gently scraping with sterile $200 \mu \mathrm{L}$ micropipette tip. The cells were then rinsed with the serum free DMEM and treated with the test samples. The scratched area was then monitored for a time period ranging from 0 to 48 hours for closure of wound area. The photomicrographs (x10) were done at the selected time point of migrated cells using digital camera. It represented fibroblast distance covered and subsequent scratch closure [39].

\subsection{Statistical Analysis}

Each experiment was carried out in three independent assays and was represented as mean values with standard error of mean (SEM). For multiple group comparison, oneway analysis of variance (ANOVA) was used followed by post-hoc analysis by Dunnett's test. Statistically significant values were set at the level of $p \leq 0.05$.

\section{Results and Discussion}

\subsection{Cell Viability by MTT Assay}

The results of cell viability using MTT assay in three different cell lines are shown in Figure 1A to 1C. The result showed approximately $>70 \%$ viable cells in the tested concentrations ranges from 0.63 to $10 \mu \mathrm{g} / \mathrm{mL}$. The selected concentrations were used for further estimation of extracellular matrix (ECM) synthesis in HFF-1 cells such as collagen, elastin, and hyaluronic acid (Figure 1A). Furthermore, the cell viability in $\mathrm{HaCaT}$ cells exhibited $>90 \%$ (Figure 1B). The tested safe concentrations from 5 to $40 \mu \mathrm{g} / \mathrm{mL}$ were used further for the evaluation of wound healing activity using a scratch assay. The percentage of viable cells in the B16-F10 cells revealed that the test formulation was non-cytotoxic (i.e. percentage cell viability value $>80 \%$ ) and was found as safe (Figure 1C). The selected test concentrations from 10 to $40 \mu \mathrm{g} / \mathrm{mL}$ were used further for the measurement of melanin level.

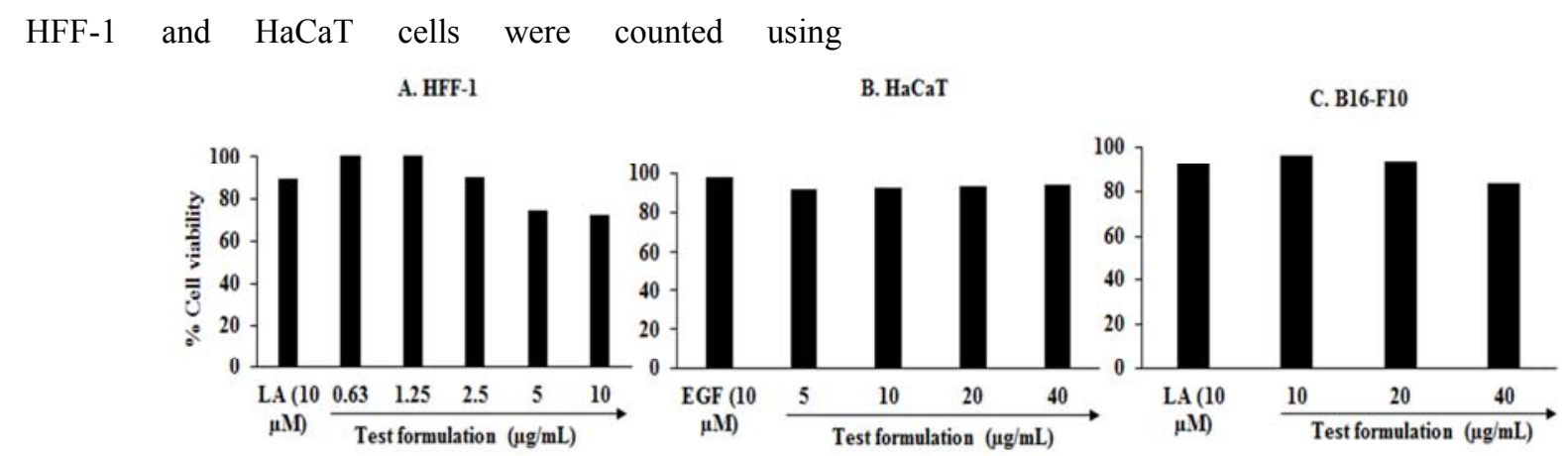

Figure 1. Percentage cell viability of the test formulation in different concentrations A. HFF-1 cells after 72 hours of treatment. B. HaCaT cells after 48 hours of treatment. C. B16-F10 cells after 48 hours of treatment. LA: L-Ascorbic acid; EGF: Epidermal growth factor. 


\subsection{Cell Proliferation by BrdU Assay}

The cell proliferation was assessed by bromodeoxyuridine (BrdU) assay and the data are depicted in Figure 2. The vehicle control (VC) group showed $100 \%$ cell proliferation. The positive control group (FBS- $0.5 \mu \mathrm{g} / \mathrm{mL}$ ) revealed
$150.4 \%$ cell proliferation compared to the VC group. The Biofield Energy Treated test formulation and DMEM result showed an alteration of the percent cell proliferation compared to the UT-DMEM + UT-Test formulation group.

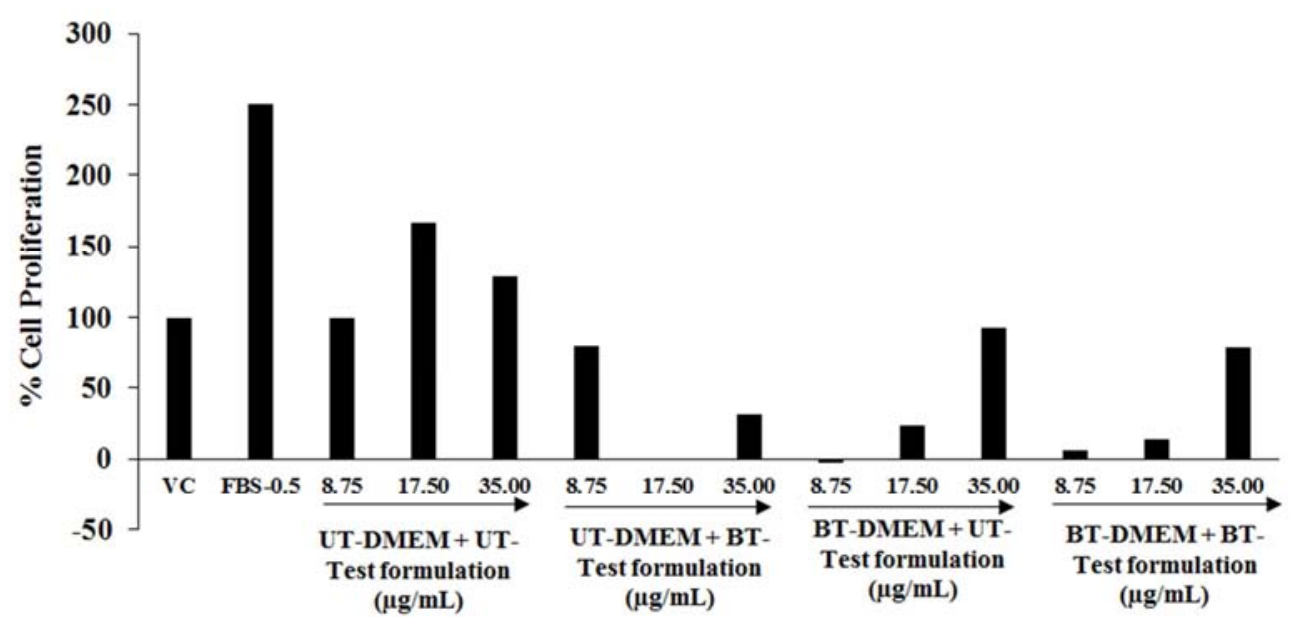

Figure 2. Effect of the test formulation on cellular proliferation after 48 hours using BrdU assay. VC: Vehicle control; FBS: Fetal bovine serum ( $\mu g / m L) ; U T$ : Untreated; BT: Biofield Treated.

\subsection{Effect of the Test Formulation on Synthesis of Extracellular Matrix (ECM) Components in Human Foreskin Fibroblast (HFF-1)}

\subsubsection{Collagen}

The effect of the test formulation and DMEM on collagen level in HFF-1 cells is shown in Figure 3. The level of collagen was significantly increased by $168.62 \%$ in the positive control group $(129.42 \pm 8.50 \mu \mathrm{g} / \mathrm{mL})$ compared to the vehicle control (VC) group $(48.18 \pm 0.34 \mu \mathrm{g} / \mathrm{mL})$. The collagen level was significantly $(p \leq 0.001)$ increased by $22.42 \%$ in the UT-DMEM + BT-Test formulation group at $0.63 \mu \mathrm{g} / \mathrm{mL}$ compared to the UT-DMEM + UT-Test formulation group. Additionally, the collagen was increased by $12.76 \%$ and $5.86 \%$ in the UT-DMEM + BT-Test formulation and BT-DMEM + BT-Test formulation groups, respectively at $1.25 \mu \mathrm{g} / \mathrm{mL}$ with respect to the UT-DMEM +
UT-Test formulation group. Further, the synthesis of collagen was increased by $17.48 \%$ and $4.93 \%$ in the UT-DMEM + BT-Test formulation and BT-DMEM + BT-Test formulation groups, respectively at $2.5 \mu \mathrm{g} / \mathrm{mL}$ with respect to the UTDMEM + UT-Test formulation group. Collagen is the fibrous protein present in the ECM and a major constituent of connective tissue in the human. In human, collagen possess approximately $3-6 \%$ of the total tissue protein. The expression of collagen was indicated by changes in various physiological processes viz. during wound healing, new bone development, and aging [40]. Overall, the Biofield Energy Treated Test formulation and DMEM have significantly improved the level of collagen synthesis, which is likely due to The Trivedi Effect ${ }^{\mathbb{B}}$ - Consciousness Energy Healing Treatment.

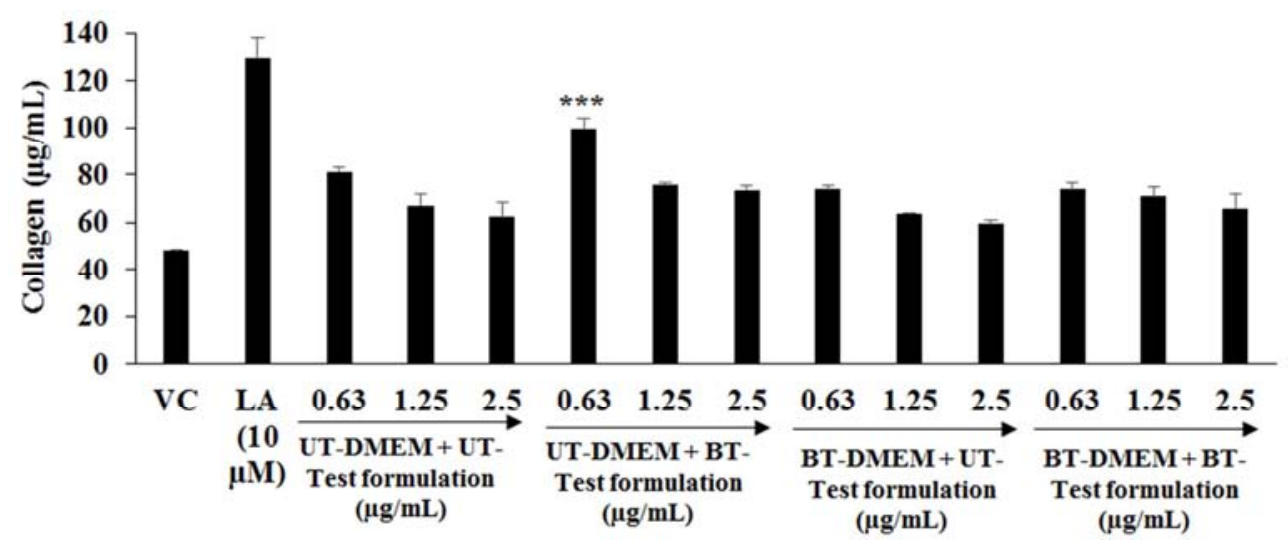

Figure 3. Effect of the test formulation on collagen synthesis in human foreskin fibroblast cells (HFF-1). VC: Vehicle control; LA: L-Ascorbic acid; UT: Untreated; BT: Biofield Treated. ${ }^{* * *} p \leq 0.001$ vs UT-DMEM + UT-Test formulation using one-way ANOVA (post-hoc Dunnett's test). 


\subsubsection{Elastin}

The effect of the Biofield Energy Treated test formulation and DMEM on elastin level is shown in Figure 4. The level of elastin was found as $6.06 \pm 0.32 \mathrm{pg} / \mathrm{mL}$ in the vehicle control (VC) group and it was increased by $49.67 \%$ in the positive control group $(9.07 \pm 0.15 \mathrm{pg} / \mathrm{mL})$. The elastin level was increased by $6.79 \%$ in the BT-DMEM + BT-Test formulation group at $2.5 \mu \mathrm{g} / \mathrm{mL}$ compared to the UT-DMEM + UT-Test formulation group. Moreover, at $5 \mu \mathrm{g} / \mathrm{mL}$ the level of elastin was significantly $(p \leq 0.001)$ increased by $28.41 \%$ in the BT-DMEM + BT-Test formulation group compared to the UT-DMEM + UT-Test formulation group. Besides, the expression of elastin was significantly $(p \leq 0.001)$ increased by $24.12 \%$ and $117.65 \%$ in the BT-DMEM + UT-Test formulation and BT-DMEM + BT-Test formulation groups, respectively at $10 \mu \mathrm{g} / \mathrm{mL}$ compared to the UT-DMEM + UTTest formulation group.

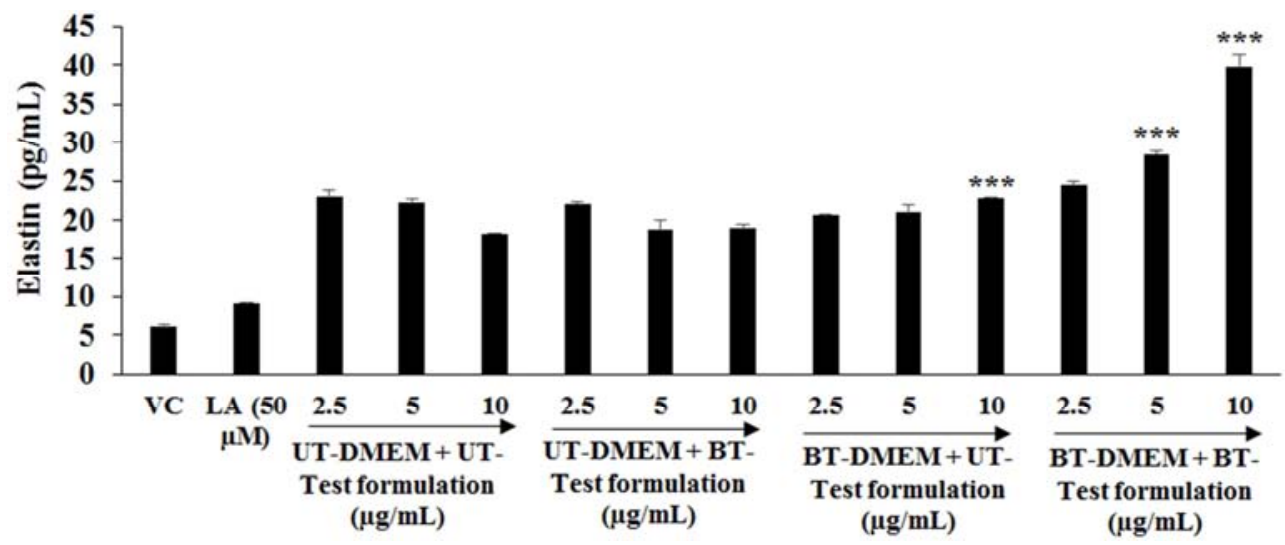

Figure 4. Effect of the test formulation on elastin in human foreskin fibroblast cells (HFF-1). VC: Vehicle control; LA: L-Ascorbic acid; UT: Untreated; BT: Biofield Treated. ${ }^{* *} p \leq 0.001$ vs UT-DMEM + UT-Test formulation using one-way ANOVA (post-hoc Dunnett's test).

\subsubsection{Hyaluronic Acid (HA)}

The effect of the test formulation with DMEM on HA level is presented in Figure 5. The results of HA synthesis in the presence of ascorbic acid $(10 \mu \mathrm{M})$, showed significant increased in HA content by $56.27 \%$ compared with the vehicle control (VC) group $(7.82 \pm 0.01 \mathrm{ng} / \mathrm{mL})$ group. The level of HA was increased by $6.69 \%$ and $15.90 \%$ in the UTDMEM + BT-Test formulation and BT-DMEM + BT-Test formulation groups, respectively at $0.63 \mu \mathrm{g} / \mathrm{mL}$ compared to the UT-DMEM + UT-Test formulation group. Further, at
$1.25 \mu \mathrm{g} / \mathrm{mL}$ the level of HA was significantly $(p \leq 0.05)$ increased by $32.46 \%$ and $17.67 \%$ in the BT-DMEM + UTTest formulation and BT-DMEM + BT-Test formulation groups, respectively compared to the UT-DMEM + UT-Test formulation group. Additionally, the level of HA was increased by $7.75 \%$ in the BT-DMEM + UT-Test formulation group with respect to the UT-DMEM + UT-Test formulation group at $2.5 \mu \mathrm{g} / \mathrm{mL}$. The overall data suggested that the Biofield Energy based test formulation and DMEM have significantly increased the synthesis of hyaluronic acid (HA).

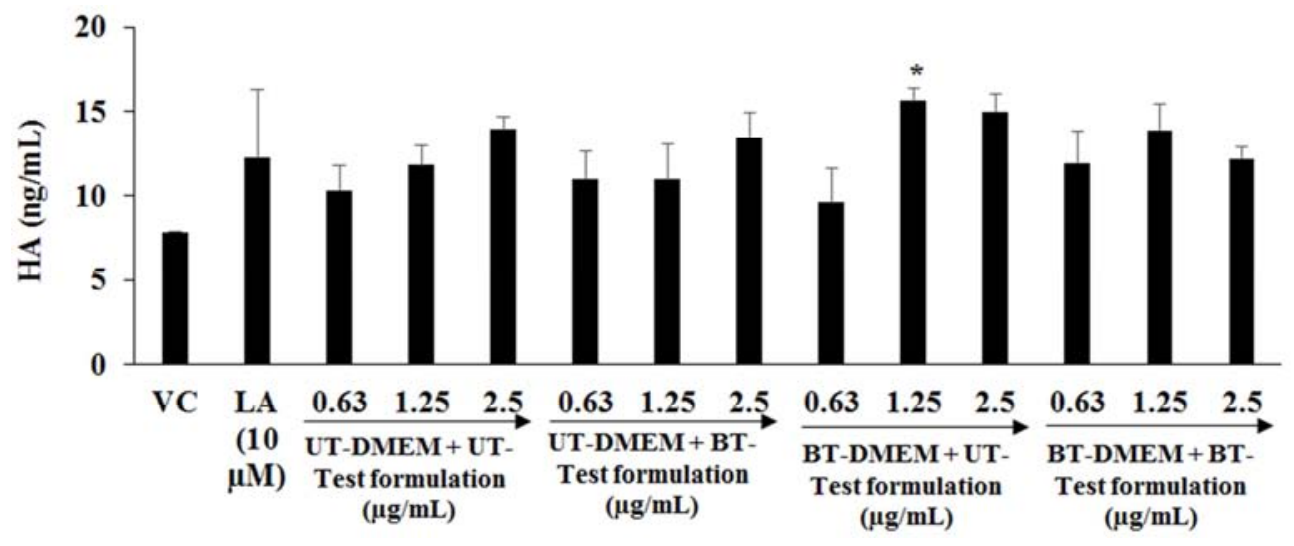

Figure 5. Effect of the test formulation on the level of hyaluronic acid (HA) in human foreskin fibroblast cells (HFF-1). VC: Vehicle control; LA: L-Ascorbic acid; UT: Untreated; BT: Biofield Treated. *p $\leq 0.05$ vs UT-DMEM + UT-Test formulation using Student's t-test).

\subsection{Effect of the Test Formulation on Skin Depigmentation}

The effect of the test formulation with DMEM on alphamelanocyte-stimulating hormone $(\alpha-\mathrm{MSH})$ stimulated melanin synthesis in B16-F10 cells is shown in Figure 6. The level of melanin in the $\alpha$-MSH group was $24.9 \pm 0.56 \mu \mathrm{g} / \mathrm{mL}$ and it was decreased by $63.49 \%$ in the kojic acid (KA) group $(9.09 \pm 3.03 \mu \mathrm{g} / \mathrm{mL})$. The cellular content of melanin was reduced by $9.25 \%$ in the BT-DMEM + BT-Test formulation 
group at $0.013 \mu \mathrm{g} / \mathrm{mL}$ with respect to the UT-DMEM + UTTest formulation group. Besides, the level of the melanin synthesis was inhibited by $4.47 \%$ and $7.26 \%$ in the BTDMEM + UT-Test formulation and BT-DMEM + BT-Test formulation groups, respectively at $0.063 \mu \mathrm{g} / \mathrm{mL}$ compared to the UT-DMEM + UT-Test formulation group. Additionally, the melanin synthesis was suppressed by $7.49 \%$ and $8.03 \%$ in the UT-DMEM + BT-Test formulation and BT-DMEM +
UT-Test formulation groups, respectively compared to the UT-DMEM + UT-Test formulation group. Thus, it can be concluded that the Biofield Energy Treated test formulation and DMEM significantly inhibit the melanin production in the B16-F10 melanoma cells. This improvement might be beneficial for the development of a cosmeceuticals for hyperpigmentation and different types of skin conditions.

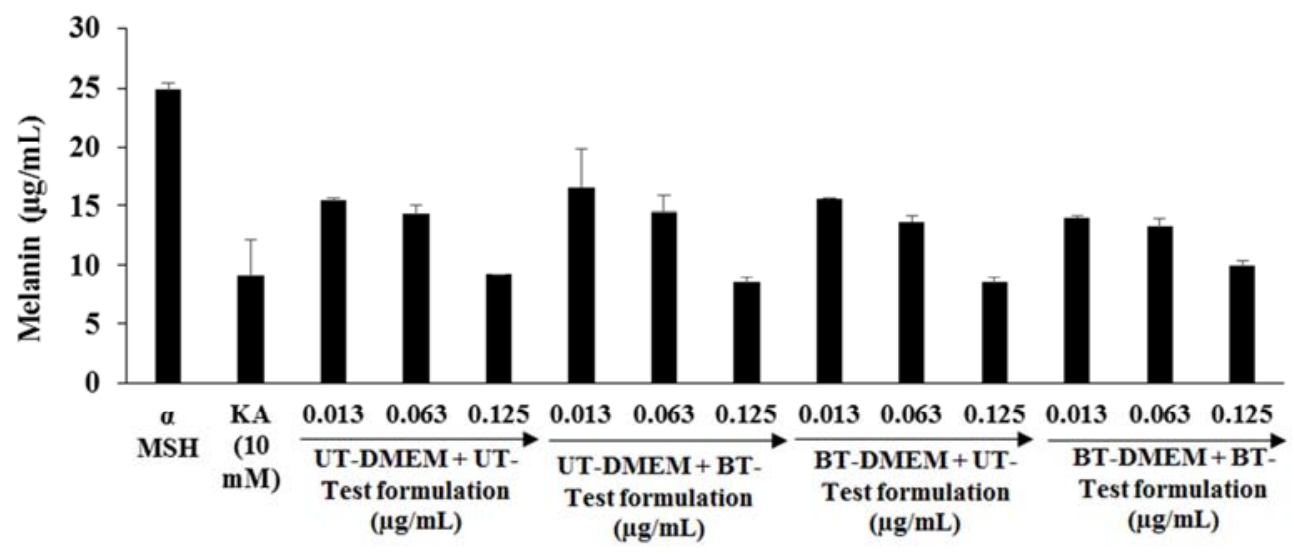

Figure 6. Effect of the test formulation and DMEM on alpha-MSH stimulated melanin level in B16-F10 cells. $\alpha$-MSH: Alpha-melanocyte-stimulating hormone, KA: Kojic acid (mM); UT: Untreated; BT: Biofield Treated.

\subsection{Anti-wrinkle Effect of the Test Formulation on HFF-1 Cells Against UV-B Induced Stress}

The effect of the test formulation and DMEM after pretreatment with the UV-B challenge is shown in Figure 7. The cell viability was estimated using hemocytometer. The cells were subjected to a lethal dose of UV-B irradiation (200 $\mathrm{mJ} / \mathrm{cm}^{2}$ ) and found $26.73 \%$ cell viability. The percent cell viability in the normal control (NC) and vehicle control groups was $100 \%$ and $27.78 \%$, respectively. Further, the cell viability was increased by $55.41 \%$ in the positive control group. Among the tested groups, BT-DMEM + BT-Test formulation showed $17.88 \%, 20.10 \%$, and $25.77 \%$ increased the percent cell viability at $0.625,1.25$, and $2.5 \mu \mathrm{g} / \mathrm{mL}$, respectively compared with the UT-DMEM + UT-Test formulation group. The rest of the groups showed an alteration of the percent cell viability to some extent. Wrinkles generally occur due to many factors such as aging, genetics, and environmental factors such as ultraviolet radiation, smoking and due to deficiency of estrogen [41-43]. Among these, aging is the most important responsible for skin wrinkles. In humans, due to aging the skin becomes thin, decrease elasticity and the content of glycosamino glycans, collagen, etc. [44, 45]. The results suggested that both the Biofield Energy Treated test formulation and DMEM could be significantly used for skin protective effect with antiwrinkling potential.

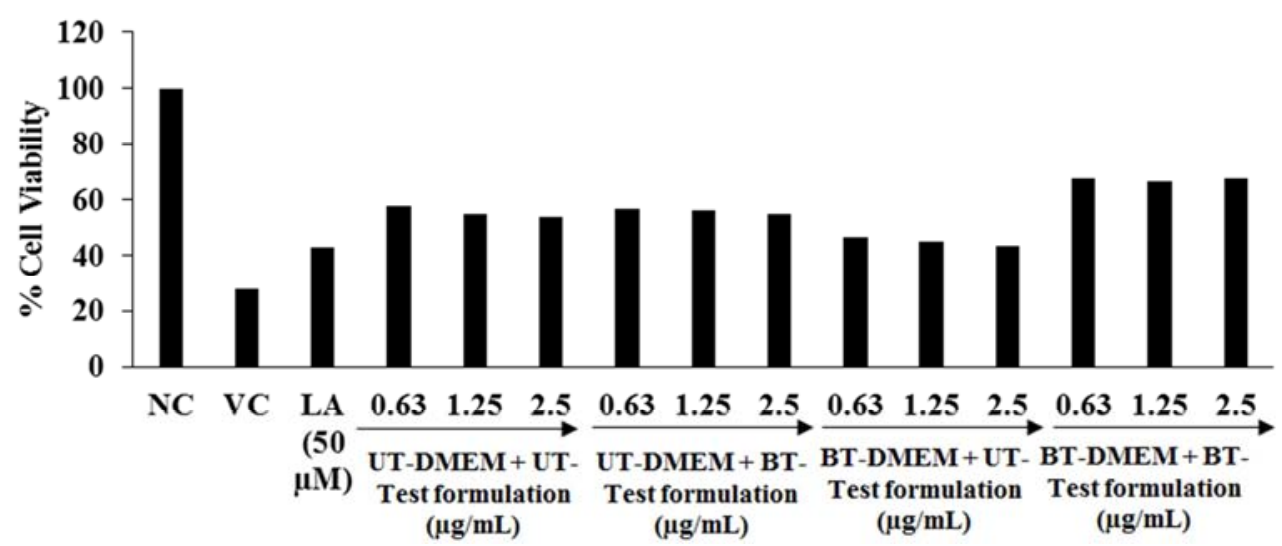

Figure 7. Percentage restoration of cell viability in HFF-1 cells after 20 hours pretreatment of the test formulation and DMEM before UV-B challenge. NC: Normal control; VC: Vehicle control LA: L-Ascorbic acid; UT: Untreated; BT: Biofield Treated

\subsection{Wound Healing Activity by Scratch Assay}

The wound healing activity of the DMEM and test formulation by scratch assay were performed to measure the wound closure and cell migration in HFF-1 and HaCaT cells. The representative photomicrographs are presented in Figure 
8. The cell coverage area was increased by $5 \%, 1 \%$, and $4 \%$ in the UT-DMEM + BT-Test formulation, BT-DMEM + UTTest formulation, and BT-DMEM + BT-Test formulation groups, respectively at $0.625 \mu \mathrm{g} / \mathrm{mL}$ in HFF- 1 cells compared to the UT-DMEM + UT-Test formulation group. Moreover, the cell coverage area was increased by $5 \%$ in the UT$\mathrm{DMEM}+\mathrm{BT}$-Test formulation and BT-DMEM + BT-Test formulation groups, respectively at $5 \mu \mathrm{g} / \mathrm{mL}$ in HFF-1 cells compared to the UT-DMEM + UT-Test formulation group
(Figure $8 \mathrm{~A}$ ). Besides, the cell coverage area was increased by $3 \%$ in the UT-DMEM + BT-Test formulation group at 10 $\mu \mathrm{g} / \mathrm{mL}$ in HaCaT cells compared to the UT-DMEM + UTTest formulation group (Figure $8 \mathrm{~B}$ ). Scratch assay for the assessment of wound healing activity in vitro is a well established method for the estimation of cell migration, cellmatrix and cell-to-cell interactions and also for monitoring the intracellular event during cell migration [46].

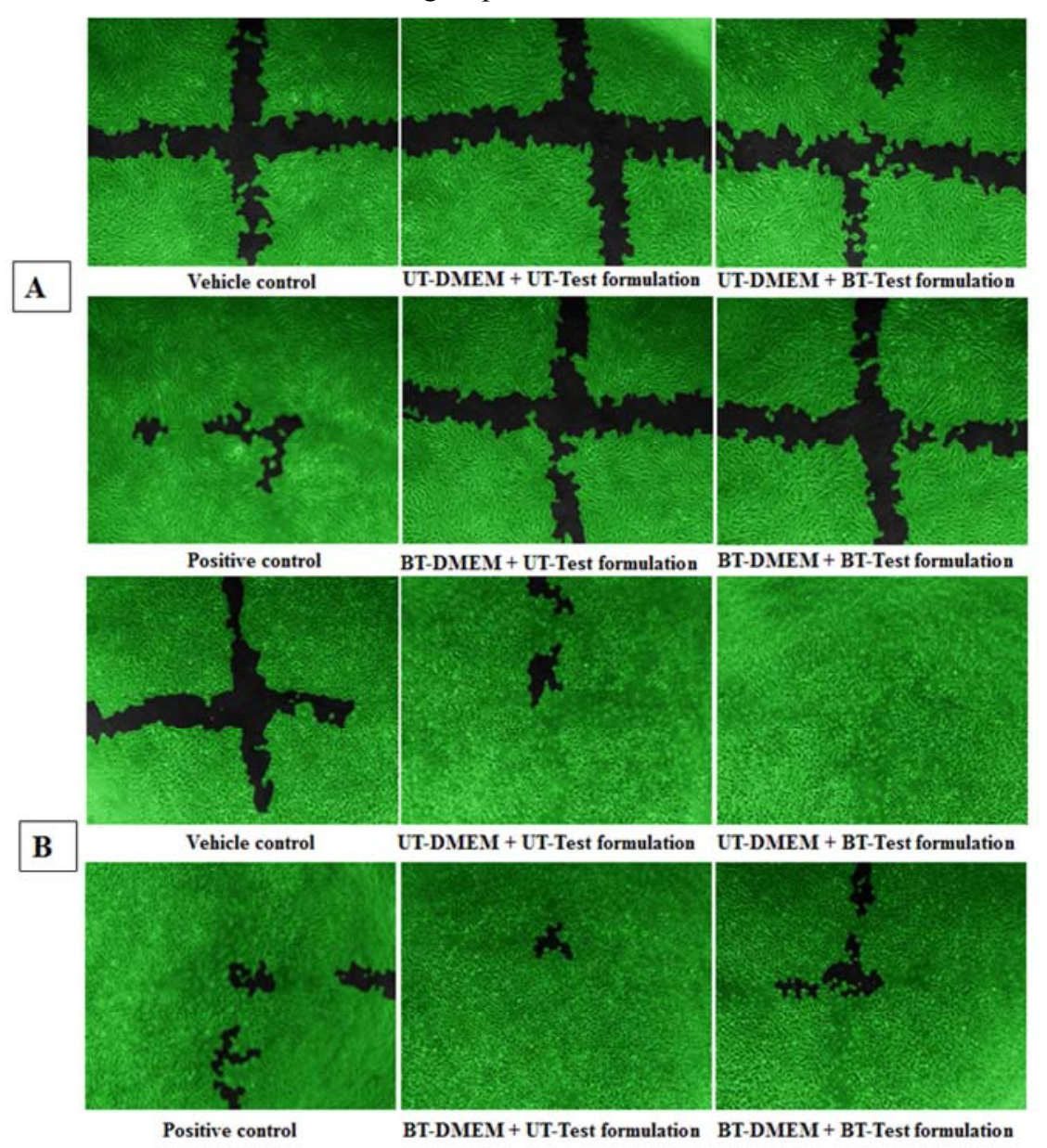

Figure 8. Effect of the test formulation and DMEM on wound healing activity after 16 hours of treatment. Representative photomicrographs (X10) of wound closure and cell migration are shown in A. HFF-1 and B. HaCaT cells. UT: Untreated; BT: Biofield Treated.

\section{Conclusions}

The study findings describe that the cell viability of the test formulation using MTT assay exhibited more than $70 \%$ cells were viable in all the tested concentrations, indicating that the test formulation was found to be safe and nontoxic. The collagen level was significantly $(p \leq 0.001)$ increased by $22.42 \%$ and $17.48 \%$ in the UT-DMEM + BT-Test formulation group at 0.63 and $2.5 \mu \mathrm{g} / \mathrm{mL}$, respectively with respect to the UT-DMEM + UT-Test formulation group. The level of elastin was significantly $(p \leq 0.001)$ increased by $28.41 \%$ in the BT-DMEM + BT-Test formulation group at 5 $\mu \mathrm{g} / \mathrm{mL}$ compared to the UT-DMEM + UT-Test formulation group. Moreover, the elastin level at $10 \mu \mathrm{g} / \mathrm{mL}$ was significantly $(p \leq 0.001)$ increased by $24.12 \%$ and $117.65 \%$ in the BT-DMEM + UT-Test formulation and BT-DMEM + BT-Test formulation groups, respectively compared to the UT-DMEM + UT-Test formulation group. Hyaluronic acid was increased significantly by $32.46 \%$ in the BT-DMEM + UT-Test formulation group compared to the UT-DMEM + UT-Test formulation group. However, it was further increased by $15.90 \%$ and $17.67 \%$ in the BT-DMEM + BTTest formulation group at 0.63 and $1.25 \mu \mathrm{g} / \mathrm{mL}$, respectively compared to the UT-DMEM + UT-Test formulation group. Melanin level was significantly reduced by $9.25 \%$ in the BT$\mathrm{DMEM}+\mathrm{BT}$-Test formulation group at $0.013 \mu \mathrm{g} / \mathrm{mL}$ with respect to the UT-DMEM + UT-Test formulation group. The anti-wrinkle activity after challenged with UV-B, revealed that the percent cell viability was significantly increased by $17.88 \%, 20.10 \%$, and $25.77 \%$ in the BT-DMEM + BT-Test 
formulation group at $0.63,1.25$, and $2.5 \mu \mathrm{g} / \mathrm{mL}$, respectively compared to the UT-DMEM + UT-Test formulation group. Wound healing results described that the cell coverage area was significantly improved in both the HFF-1 and all HaCaT cells compared to the untreated group. Altogether, the Consciousness Energy Healing Treated (The Trivedi Effect ${ }^{\circledR}$ ) test formulation and DMEM showed significant protective effects on various skin health parameters such as wrinkling, aging, skin whitening, and wound healing. Therefore, the Biofield Energy Healing and the Treated test formulation could be suitable for the development of herbal cosmetics, which would be useful for the management of wounds and various skin related disorders like contact dermatitis, pimples, cellulitis, impetigo, chickenpox, scabies, syringoma, rosacea, photosensitivity, urticaria, hives, warts, abscess, callus, acne, eczema, seborrheic dermatitis, athlete's foot, psoriasis, abscess, erythema, cutis rhomboidalis nuchae, skin aging, wrinkles and/or change in skin color etc.

\section{Abbreviations}

ATCC: American type culture collection, NCCS: National centre for cell science, HaCaT: Human keratinocytes, HFF-1: Human fibroblast cell line, B16-F10: Mouse melanoma cell line, THC: Tetrahydrocurcumin, ECM: Extracellular matrix, EGF: Epidermal growth factor, $\alpha$-MSH: Alpha-melanocytestimulating hormone, ANOVA: One-way analysis of variance, HA: Hyaluronic acid, UT: Untreated, BT: Biofield Treated, FBS: Fetal bovine serum, BrdU: Bromodeoxyuridine, ROS: Reactive oxygen species, CAM: Complementary and alternative medicine, DMEM: Dulbecco's modified eagle's medium, UV: Ultra-violet.

\section{Acknowledgements}

Authors are grateful to Dabur Research Foundation, Trivedi Global, Inc., Trivedi Science, Trivedi Testimonials, and Trivedi Master Wellness for their support throughout the work.

\section{References}

[1] Tabassum N, Hamdani M (2014) Plants used to treat skin diseases. Pharmacogn Rev 8: 52-60.

[2] Goyal RK (2005) Investigation of cellular and molecular mechanisms for anti-diabetic drugs with special reference to Unani and Ayurvedic herbal medicines. In: Traditional system of medicine, Abdin, M. Z. and Y. P. Abrol (Eds.). Narosa Publishing House, New Delhi.

[3] WHO (1993) Research Guideline for Evaluating the Safety and Efficacy of Herbal Medicines. World Health Organization, Manila, Philippines.

[4] Park K (2015) Role of micronutrients in skin health and function. Biomol Ther (Seoul) 23: 207-217.

[5] McDaniel S, Goldman GD (2002) Consequences of using escharotic agents as primary treatment for nonmelanoma skin cancer. Arch Dermatol 138: 1593-1596.

[6] Dziaman T, Huzarski T, Gackowski D, Rozalski R, Siomek A, Szpila A, Guz J, Lubinski J, Wasowicz W, Roszkowski K, Olinski R (2009) Selenium supplementation reduced oxidative DNA damage in adnexectomized BRCA1 mutations carriers. Cancer Epidemiol Biomarkers Prev 18: 2923-2928.

[7] Spallholz JE (2001) Selenium and the prevention of cancer Part II: Mechanisms for the carcinostatic activitiy of Se compounds. The Bulletin of Selenium-Tellurium Development Association. 2001: 12.

[8] Combs GF Jr., Clark LC, Turnbull BW (1997) Reduction of cancer mortality and incidence by selenium supplementation. Med Klin (Munich) 92: 42-45.

[9] Combs GF Jr., Clark LC, Turnbull BW (1997) Reduction of cancer risk with an oral supplement of selenium. Biomed Environ Sci 10: 227-234.

[10] Institute of Medicine (IOM), (2001). Dietary Reference Intakes for Vitamin A, Vitamin K, Arsenic, Boron, Chromium, Copper, Iodine, Iron, Manganese, Molybdenum, Nickel, Silicon, Vanadium, and Zinc. Food and Nutrition Board. Washington, DC, USA (Ed.), National Academy Press, Washington, DC, pp. 420-441.

[11] Kisker C, Schindelin H, Rees DC (1997) Molybdenumcofactor-containing enzymes: Structure and mechanism. Annu Rev Biochem 66: 233-267.

[12] Boyera N, Galey I, Bernard BA (1998) Effect of vitamin C and its derivatives on collagen synthesis and cross-linking by normal human fibroblasts. Int J Cosmet Sci 20: 151-158.

[13] Sugiyama Y, Kawakishi S, Osawa T (1996) Involvement of the $\beta$-diketone moiety in the antioxidant mechanism of tetrahydrocurcuminoids. Biochem Pharmacol 52: 519-525.

[14] Lai CS, Wu JC, Yu SF, Badmaev V, Nagabhushanam K, Ho CT, Pan MH (2011) Tetrahydrocurcumin is more effective than curcumin in preventing azoxymethane-induced colon carcinogenesis. Mol Nutr Food Res 55: 1819-1828.

[15] Hashim P (2011) Centella asiatica in food and beverage applications and its potential antioxidant and neuroprotective effect. Int Food Res J 18: 1215-1222.

[16] Hong SS, Kim JH, Shim CK (2005) Advance formulation and pharmacological activity of hydrogel of titrated extract of Centella asiatica. Arch Pharma Res 28: 502-508.

[17] Shetty BS, Udupa AL, Somayaji SN (2006). Effect of Centella asiatica L. on normal and dexamethasone suppressed wound healing in Wistar Albino rats. Int J Low Extrem Wounds 5: 137-143.

[18] Hammerschlag R, Jain S, Baldwin AL, Gronowicz G, Lutgendorf SK, Oschman JL, Yount GL. (2012) Biofield research: A roundtable discussion of scientific and methodological issues. J Altern Complement Med 18: 10811086.

[19] Movaffaghi Z, Farsi M (2009) Biofield therapies: Biophysical basis and biological regulations? Complement Ther Clin Pract 15: 35-37.

[20] Sun Y, Wang C, Dai J (2010) Biophotons as neural communication signals demonstrated by in situ biophoton autography. Photochem Photobiol Sci 9: 315-322. 
[21] Yount G, Patil S, Dave U, Alves-dos-Santos L, Gon K, Arauz R, and Rachlin K (2013) Evaluation of biofield treatment dose and distance in a model of cancer cell death. J Altern Complement Med 19: 124-127.

[22] Garland SN, Valentine D, Desai K, Li S, Langer C, Evans T, Mao JJ (2013) Complementary and alternative medicine use and benefit finding among cancer patients. J Altern Complement Med 19: 876-881.

[23] Trivedi MK, Tallapragada RM (2008) A transcendental to changing metal powder characteristics. Met Powder Rep 63: $22-28,31$.

[24] Trivedi MK, Nayak G, Patil S, Tallapragada RM, Latiyal O (2015) Studies of the atomic and crystalline characteristics of ceramic oxide nano powders after bio field treatment. Ind Eng Manage 4: 161 .

[25] Dabhade VV, Tallapragada RR, Trivedi MK (2009) Effect of external energy on atomic, crystalline and powder characteristics of antimony and bismuth powders. Bull Mater Sci 32: 471-479.

[26] Sances F, Flora E, Patil S, Spence A, Shinde V (2013) Impact of biofield treatment on ginseng and organic blueberry yield. Agrivita J Agric Sci 35: 22-29.

[27] Lenssen AW (2013) Biofield and fungicide seed treatment influences on soybean productivity, seed quality and weed community. Agricultural Journal 83: 138-143.

[28] Trivedi MK, Patil S, Shettigar H, Gangwar M, Jana S (2015) Antimicrobial sensitivity pattern of Pseudomonas fluorescens after biofield treatment. J Infect Dis Ther 3: 222.

[29] Trivedi MK, Patil S, Shettigar H, Bairwa K, Jana S (2015) Phenotypic and biotypic characterization of Klebsiella oxytoca: An impact of biofield treatment. J Microb Biochem Technol 7: 203-206.

[30] Trivedi MK, Patil S, Shettigar H, Gangwar M, Jana S (2015) An effect of biofield treatment on multidrug-resistant Burkholderia cepacia: A multihost pathogen. J Trop Dis 3: 167.

[31] Patil SA, Nayak GB, Barve SS, Tembe RP, Khan RR (2012) Impact of biofield treatment on growth and anatomical characteristics of Pogostemon cablin (Benth.). Biotechnology 11: 154-162.

[32] Nayak G, Altekar N (2015) Effect of biofield treatment on plant growth and adaptation. J Environ Health Sci 1: 1-9.

[33] Biological evaluation of medical devices - Part 5: Tests for in vitro cytotoxicity (ISO 10993-5:2009), I.S.EN ISO, 10993-5: 2009.
[34] Junquiera LC, Junqueira LC, Brentani RR (1979) A simple and sensitive method for the quantitative estimation of collagen. Anal Biochem 94: 96-99.

[35] Hahn MS, Kobler JB, Starcher BC, Zeitels SM, Langer R (2006) Quantitative and comparative studies of the vocal fold extracellular matrix. I: Elastic fibers and hyaluronic acid. Ann Otol Rhinol Laryngol 115: 156-164.

[36] Zhang L, Yoshida T, Kuroiwa Y (1992) Stimulation of melanin synthesis of B16-F10 mouse melanoma cells by bufalin. Life Sci 51: 17-24.

[37] Fronza M, Heinzmann B, Hamburger M, Laufer S, Merfort I (2009) Determination of the wound healing effect of Calendula extracts using the scratch assay with 3T3 fibroblasts. J Ethnopharmacol 126: 463-467.

[38] Wen KC, Shih IC, Hu JC, Liao ST, Su TW, Chiang HM (2011) Inhibitory effects of Terminalia catappa on UV-B-induced photodamage in fibroblast cell line. Evid Based Complement Alternat Med 2011: 904532.

[39] Rozario T, DeSimone DW (2010) The extracellular matrix in development and morphogenesis: A dynamic view. Dev Biol 341: $126-140$.

[40] Cardinale GJ, Udenfriend S (1974) Prolyl hydroxylase. Adv Enzymol Relat Areas Mol Biol 41: 245-300.

[41] Yin L, Morita A, Tsuji T (2001) Skin aging induced by ultraviolet exposure and tobacco smoking: Evidence from epidemiological and molecular studies. Photodermatol Photoimmunol Photomed 17: 178-183.

[42] Castelo-Branco C, Figueras F, Martínez de Osaba MJ, Vanrell JA (1998) Facial wrinkling in postmenopausal women. Effects of smoking status and hormone replacement therapy. Maturitas 29: 75-86.

[43] Youn CS, Kwon OS, Won CH, Hwang EJ, Park BJ, Eun HC, Chung JH (2003) Effect of pregnancy and menopause on facial wrinkling in women. Acta Derm Venereol 83: 419-424.

[44] Contet-Audonneau JL, Jeanmaire C, Pauly G (1999) A histological study of human wrinkle structures: comparison between sun-exposed areas of the face, with or without wrinkles, and sun-protected areas. Br J Dermatol 140: 10381047.

[45] Brincat M, Moniz CJ, Studd JW, Darby A, Magos A, Emburey G, Versi E (1985) Long-term effects of the menopause and sex hormones on skin thickness. Br J Obstet Gynaecol 92: 256259.

[46] Frantz C, Stewart KM, Weaver VM (2010) The extracellular matrix at a glance. J Cell Sci 123: 4195-4200. 